\title{
Interactions between estrogen and insulin-like growth factor signaling pathways in human breast tumor cells
}

\author{
I H L Hamelers and P H Steenbergh
}

Utrecht Graduate School of Developmental Biology, Department of Physiological Chemistry, University Medical Center Utrecht, PO Box 85060, 3508 AB Utrecht, The Netherlands

(Requests for offprints should be addressed to P H Steenbergh; Email: P.H.Steenbergh@med.uu.nl)

\begin{abstract}
Estrogens and insulin-like growth factors (IGFs) act as mitogens promoting cell proliferation in normal breast tissue as well as in breast carcinomas. Both hormones have been shown to play a role in the development of breast cancer and were found to activate multiple signaling pathways leading to proliferation of human breast cancer cell lines in vitro. Originally, it was considered that these agents manifest their mitogenic actions through separate pathways, but a growing body of evidence suggests that the IGF- and estrogen-mediated signaling pathways are intertwined. 17ß-Estradiol (E2) has been shown to enhance IGF signaling at multiple levels. E2 treatment of breast cancer cells alters expression of nearly all of the IGF family members including IGF-I, IGF-II, IGF-binding proteins, IGF type I receptor (IGF-RI), and insulin receptor substrate 1. The ligand-bound estrogen receptor has been reported to bind to and to activate the IGF-RI directly. Vice versa, IGF signaling has been reported to enhance estrogen receptor activation in human breast cancer cells by inducing phosphorylation of the estrogen receptor. Finally, several groups have described synergistic effects of the combination of E2 and IGF-I on S phase entry in breast tumor cell lines. Here, we review recent, often contradictory, reports describing the effects of E2 and IGFs on the proliferation of breast tumor cells, with special emphasis on the synergistic effects of the two hormones.
\end{abstract}

Endocrine-Related Cancer (2003) 10 331-345

\section{Introduction}

Breast cancer is the most common cancer in women worldwide and continues to be a major health problem (Harris et al. 1992, Henderson 1993, Garfinkel et al. 1994, Henson \& Tarone 1994). Research in breast cancer now extends in many directions, from identification of genes that predispose to breast cancer, to cellular models for preneoplastic disease, to investigation of the tumor and its local environment, and to identification of environmental risk factors for the development of breast cancer.

For some tumors, like colorectal cancer, the most common sequence of genetic events and their timing, eventually leading to tumor formation, has been determined (Fearon \& Vogelstein 1990). In contrast to colorectal cancer, pathological findings in breast cancer are highly variable (Beckmann et al. 1997). The evolution of breast cancer and the relationships of genetic predisposing factors with somatic changes are very complicated. Table 1 shows some of the genetic and hormonal factors that are involved in the development of breast cancer and progression of the disease. Sev-
Table 1 Genetic and hormonal factors involved in the development and progression of breast cancer

\begin{tabular}{lll}
\hline & $\begin{array}{l}\text { Gene, hormone, } \\
\text { or growth factor }\end{array}$ & Reference \\
\hline $\begin{array}{l}\text { Predisposing } \\
\text { genetic factors }\end{array}$ & BRCA1 and 2 & Venkitaraman (2002) \\
& $p 53$ & $\begin{array}{l}\text { Blackburn \& Jerry } \\
(2002)\end{array}$ \\
Hormones and & Estrogen, & Portier (2002) \\
growth factors & $\begin{array}{l}\text { progesterone, } \\
\text { and prolactin } \\
\text { IGFs }\end{array}$ & \\
& EGF & $\begin{array}{l}\text { Sachdev \& Yee (2001) } \\
\text { Biscardi et al. (2000) } \\
\text { TGF } \beta\end{array}$ \\
& Wakefield et al. (2001) \\
\hline
\end{tabular}

eral genetic alterations have been associated with an increased risk of breast cancer development. Mutations in two breast cancer susceptibility genes, BRCA 1 and 2 have been shown to predispose women to breast cancer, however mutations in these genes account for only $5 \%$ of breast 
cancer cases. The factors responsible for the remaining $95 \%$ are still obscure (Venkitaraman 2002). A significant proportion of sporadic breast cancers show point mutations clustered within exons 5-8 of the p53 gene (Blackburn \& Jerry 2002).

Other factors known to be involved in breast cancer development are hormones and growth factors. The finding that breast cancer is rare in males as well as in non-estrogenized women suggests that most, if not all, breast cancers originate as a hormone-dependent disease. Moreover, prolonged estrogen exposure, caused by early menarche (MacMahon et al. 1970), late menopause (Trichopoulos et al. 1972) or late age at first pregnancy (MacMahon et al. 1970) is associated with increased risk of developing breast cancer. Abundant evidence indicates that other hormones, like insulin-like growth factors (IGFs), epidermal growth factor (EGF), and transforming growth factor (TGF)- $\beta$ affect breast cancer growth as well (Biscardi et al. 2000, Sachdev \& Yee 2001, Wakefield et al. 2001, Portier 2002). Studies from several laboratories have shown that IGF-I and IGF-II are potent mitogens for breast cancer cells (Ellis et al. 1996, Dufourny et al. 1997), and may act synergistically with estrogen to stimulate cell proliferation (Van der Burg et al. 1988). When their actions are blocked, inhibition of tumor growth is observed (Osborne et al. 1990). This review will focus on the importance of estrogen and IGFs in the development of breast cancer, and of the signaling pathways activated by the two hormones, leading to cell proliferation of breast cancer cells. In particular, the mechanisms proposed for the observed synergistic actions of estrogens and IGF will be reviewed.

\section{Estrogen signaling in breast cancer}

Clinical studies on estrogen deficiency syndromes in humans (Pertzelan et al. 1982) have implicated estrogen in the normal development of the breast. Definitive evidence for the importance of estrogen signaling in normal mammary gland development has been obtained from experiments in mice. First, castrated immature mice do not show ductal growth through the fat pad of the mammary gland, signifying that mammary ductal development is hormone dependent (Borellini \& Oka 1989). Secondly, the mammary glands of ovariectomized mice are stimulated to grow by implanted estrogen pellets (Daniel et al. 1987), and implants of pure anti-estrogens inhibit mammary growth in intact mice (Silberstein et al. 1994). Finally, female estrogen receptor (ER) knockout mice develop mammary glands with only vestigial ducts present at the nipples (Korach 1994).

Epidemiological data strongly suggest an association between estrogens and the risk of breast cancer. The estrogen responsiveness of malignant breast epithelial cells has been demonstrated in culture and in tumor xenografts in nude mice (Shafie 1980). The primary physiological effects of estrogen are therefore major factors in both development and progression of the disease (Lupulescu 1993).

In general, estrogens induce their physiological effects through an interaction with ERs, of which two isoforms ( $\alpha$ and $\beta$ ) have been identified. The ERs are members of the steroid hormone-thyroid hormone-retinoic acid receptor superfamily of nuclear transcription factors (Tsai \& O’Malley 1994, Beato et al. 1995, Beato \& Klug 2000). Six

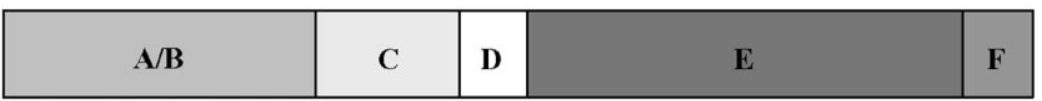

\begin{tabular}{lll}
\hline Domain & Domain function & Difference in $\alpha / \beta$ isoform \\
\hline A/B & $\begin{array}{l}\text { Constitutive transcription activation (AF-1; } \\
\text { cell- and promoter-specific activity) }\end{array}$ & $\begin{array}{l}\text { Domain with the biggest differences in sequence } \\
\text { In ER } \alpha \text { AF-1 activity much stronger }\end{array}$ \\
C & $\begin{array}{l}\text { DNA binding } \\
\text { NLS }\end{array}$ & - \\
D & Hinge:Transcriptional repression & - \\
E & $\begin{array}{l}\text { Estrogen-dependent transcription activation } \\
\text { (AF-2; cell- and promoter-specific activity) } \\
\text { Hormone binding } \\
\text { Co-factor binding } \\
\text { dimerization }\end{array}$ & Some devergence in sequence \\
& $?$ & No difference in AF-2 activities \\
F & &
\end{tabular}

Figure 1 Schematic representation of the ER, showing the different domains and their function. NLS, nuclear localization signal. 
conserved functional domains, A-F, are common structural features of this family of proteins (Fig. 1) (Gronemeyer 1991). The A/B region in the amino-terminal end of the protein shows the highest variability in sequence and size among the family members. This domain was shown to contain a constitutive, hormone-independent transcription activation function (AF-1) (Tora et al. 1989, Gronemeyer 1991). Domain $\mathrm{C}$ encompasses two zinc finger DNA-binding motifs responsible for recognition of the cis-acting hormone response element, and a nuclear localization signal (NLS). The $\mathrm{D}$ or hinge region may be involved in steroid-mediated transcriptional repression (Adler et al. 1988). The E domain, the most complex region, contains the hormone-binding site, the region required for stable dimerization of the receptor, and a second estrogen-inducible transcription activation function (AF-2) (Tora et al. 1989, Gronemeyer 1991). The function of the $\mathrm{F}$ region is presently unclear, a possible interaction with cell type-specific factors that regulate ER function has been proposed (Montano et al. 1995).

Although ER $\alpha$ was cloned over 10 years ago (Green et al. 1986), ER $\beta$ has been discovered only recently (Mosselman et al. 1996, Kuiper et al. 1996). ER $\alpha$ and ER $\beta$ diverged early during evolution (Kelley \& Thackray, 1999), and differ mostly in the N-terminal A/B domain and to a lesser extent in the ligand-binding domain (E domain). These differences suggest that the two receptors could serve distinct actions. Indeed, their transcription activation domains, AF-1 and AF-2, display activities that are promoter and cell-type specific (Tora et al. 1989, McInerney et al. 1998, Cowley \& Parker 1999). Cowley \& Parker (1999) have shown that the AF-1 activity of ER $\beta$ is weak, compared with that of $E R \alpha$, on estrogen-responsive promoters, whereas their AF-2 activities are similar.

In the classical model of estrogen action, estrogens bind the $\mathrm{E}$ region in the ER, thereby inducing an allosteric conformational change, which facilitates dimerization of the receptor. The receptor dimer then binds with high affinity to DNA, resulting in activation of transcription (Tsai \& O'Malley 1994). Targets of classical estrogen action include many genes involved in proliferative signaling and cell cycle progression, i.e. cyclin D1, c-fos, c-jun, c-myc and c-myb (Loose-Mitchell et al. 1988, Weisz \& Bresciani 1993, May \& Westley 1995, Altucci et al. 1996). Other gene products, like $\mathrm{p} 21^{\text {cipl/wafl }}, \mathrm{p} 27^{k i p l}$, and TGF $\beta$, which prevent cell cycle progression, have been shown to be down-regulated by $17 \beta$ estradiol (E2) treatment of an epithelial breast cancer-derived ER-positive cell line (MCF-7) (May \& Westley 1995, Foster et al. 2001).

Several co-activators (SRC-1, TIF2, AIB1, CBP and P/ $\mathrm{CAF}$ ) and co-repressors (N-CoR and SMART) have been shown to modulate the transcriptional activity of the ER. In the absence of ligand, the ER is unable to bind steroid receptor co-activators (SRCs) directly, as its leucine-rich co-activator interaction motif (in the $\mathrm{E}$ domain) is sterically unavailable for interaction. Binding of estrogen to ER exposes AF-2 and allows recruitment of SRCs to the ER, leading to its activation. However, recently a hormoneindependent binding of SRCs to the ER has been described by Zwijsen et al. (1997, 1998). They have shown that hormone-independent binding of cyclin D1 to the ER provides a leucine-rich interaction motif in the carboxy terminus of cyclin D1 for SRCs to bind to the cyclin D1/ER complex. The binding of SRCs to the motif in cyclin D1 has been shown to result in partial activation of the ER. When estrogen is added to this complex, it binds to the ER and thereby exposes a second leucine-rich binding motif inducing co-operative recruitment of SRCs to the complex. In this way, cyclin D1 and E2 can synergistically activate the ER (Zwijsen et al. 1997, 1998).

$\mathrm{ER} \alpha$ and $\mathrm{ER} \beta$ knockout mice have demonstrated strikingly different expression patterns and functions of the two ERs (Krege et al. 1998, Couse \& Korach 1999). ER $\beta$ knockout mice show normal mammary gland development and lactation, whereas ER $\alpha$ knockout mice exhibit an estrogen-insensitive undeveloped mammary gland. ER $\beta$ thus does not seem to play an important role in proliferation of hormone-dependent breast cancer cells. ER $\beta$ expression is often down-regulated in breast cancer tissue when compared with expression in normal breast tissue (Iwao et al. 2000, Roger et al. 2001). Experiments in the human ER-negative MDA-MB-231 breast cancer cell line engineered to express functional $\operatorname{ER} \beta$ have shown that $\operatorname{ER} \beta$ expression inhibits proliferation, and decreases cell motility (Lazennec et al. 2001). This study has indicated that ER $\beta$ may even act as an inhibitor of breast cancer development, rather than inducing a mitogenic response like ER $\alpha$ (Ferguson \& Davidson 1997). The expression of $\mathrm{ER} \alpha$ is generally considered as a marker of breast cancer steroid hormone sensitivity (McGuire, 1978). The most widely used and highly successful group of drugs used in treatment of ER $\alpha$-positive breast cancers are the anti-estrogens, which interfere with ligand-receptor binding (Early Breast Cancer Trialists Collaborative Group 1992, Kinsinger et al. 2002). The expression or function of ER $\alpha$ is often lost during progression of breast cancer (Clarke et al. 1989, Murphy \& Watson 2002). Surprisingly, tumors lacking $\mathrm{ER} \alpha$ expression are generally associated with poorer histological differentiation, higher growth fraction and worse clinical outcome than ER-positive cancers. This apparent paradox may be explained by the observation that $\operatorname{ER} \alpha$ is only detected in tumor cells in a well-differentiated state. De-differentiated, fast growing carcinoma cells have often reached a hormone-independent state (reviewed in Lapidus et al. 1998).

In addition to the 'genomic' pathway of estrogen action, a growing number of reports have suggested that estrogens can act via additional signaling pathways in breast cancer cells. Numerous reports have linked E2 signaling to the 
activation of cytoplasmic signaling cascades. An overview of the pathways, which have been described to be activated by E2, is presented in Table 2. Direct activation of the extracellular signal-regulated kinase (ERK)-1 and -2 cascade has been demonstrated by several laboratories. Migliaccio et al. (1996, 1998) and Castoria et al. (1999) have shown that the E2/ER complex binds and activates c-src in MCF-7 breast cancer cells. Activated c-src phosphorylates Shc, which then associates with the Grb2/mSos complex. Subsequently c-rafl, p2 $1^{\text {ras }}$ and ERK are activated. These authors have shown that activation of the ERK pathway is essential in the induction of cell proliferation by inhibiting this pathway with the MEK-inhibitor (MEK, MAP kinase kinase) PD98059. Furthermore, they have shown that the induction of cell cycle progression is not dependent on ER-induced transcriptional activity since a transcriptionally inactive mutant of ER is able to induce S phase entry. Improta-Brears et al. (1999) have confirmed the activation of the ERK pathway by E2. How- ever, these investigators have not been able to detect any activation of c-rafl within the limits of their assay and have concluded that c-rafl is not an important component of E2mediated ERK activation. Rather, they have demonstrated that addition of E2 to the culture medium of MCF-7 cells causes a release of intracellular calcium and that this leads to activation of ERK.

Several studies have reported the activation of the phosphatidylinositol 3-kinase (PI3-kinase) route by E2 in MCF-7 breast carcinoma cells. Castoria et al. (2001) have shown that E2 activates PI3-kinase signaling in addition to the ERK pathway. According to these authors, the activated ER forms a ternary complex with c-src and p85 $\alpha$ in an E2-dependent fashion. The formation of this ternary complex results in the activation of the PI3-kinase and of protein kinase B (PKB; Akt). Furthermore, they have shown that inhibition of the PI3-kinase pathway with the PI3 kinase inhibitor LY294002 inhibits E2-induced cyclin D1 upregulation and cell cycle

Table 2 Non-genomic, mitogenic estrogen signaling in MCF-7 breast cancer cells: activation of cytoplasmic signaling cascades

\begin{tabular}{lll}
\hline $\begin{array}{l}\text { Activated protein/ } \\
\text { signaling cascade }\end{array}$ & Reference & Mechanism of activation \\
\hline ERK1 and 2 & $\begin{array}{l}\text { Migliaccio et al. (1996), } \\
\text { Castonia et al. (1999) }\end{array}$ & $\begin{array}{l}\text { The E2/ER complex binds to } \\
\text { C-SRC. This results in the } \\
\text { activation of the p21 }\end{array}$ \\
& $\begin{array}{l}\text { ras } / \text { ERK } \\
\text { pathway } \\
\text { Improta-Brears et al. }\end{array}$ & $\begin{array}{l}\text { Mobilization of intracellular } \\
\text { calcium }\end{array}$ \\
& $(1999)$ &
\end{tabular}

P13-kinase Castoria et al. (2001)

Sun et al. (2001)

\section{Akt1}

No direct activation of cytoplasmic signaling cascades
Ahmad et al. (1999) ?

Lobenhofer et al. (2000) -

$E R \alpha$ interacts with src and the p85 $\alpha$ subunit of P13-kinase and activates the kinase.

Subsequently, Akt is activated. $\mathrm{ER} \alpha$ interacts with $\mathrm{p} 85 \alpha$ subunit of P13-kinase and activates the kinase. Subsequently, Akt2 is activated.

$?$

pathways did result in a reduced mitogenic response. No phosphorylation or activation of either ERK or P13-kinase was detected directly after addition of E2 to the cells.

No activation of ERK, Jun-kinase, p38MAPK, or PKA could be detected after addition of E2 to the cells.

No activation of PKB (Akt) or ERK was found up to $1 \mathrm{~h}$ after addition of E2 (activity measured in kinase assays). 
progression (Castoria et al. 2001). Sun et al. (2001) have found an interaction of ER with $\mathrm{p} 85 \alpha$ as well, which leads to the activation of PI3-kinase and Akt2 pathway. In contrast to Castoria et al. (2001) they have shown that the interaction of the ER and $\mathrm{p} 85 \alpha$ is ligand independent. The activation of PKB (Akt) has been confirmed by a report from Ahmad et al. (1999). The mechanisms by which E2 activates PKB have not been investigated. Activation of PKB by E2 has been shown to result in enhanced proliferation and survival of the MCF-7 cells (Ahmad et al. 1999).

Other reports have shown no direct activation of ERK and PI3-kinase signaling cascades by E2. Lobenhofer and colleagues (2000) have shown that treatment of MCF-7 cells with inhibitors of the PI3-kinase and the ERK pathway results in reduced cell cycle progression in E2-stimulated cells. However, they have not detected any phosphorylation or activation of either ERK or PI3-kinase after addition of E2 to the cells. They have concluded that either basal activity or delayed activation of these kinases is essential for E2induced cell cycle progression. Caristi et al. (2001) and Hamelers et al. (2002a) have not detected any activation of cytoplasmic signaling cascades, in spite of close examination of the activity of PKA, p38MAPK, Jun-kinase (Caristi et al. 2001), ERK (Caristi et al. 2001, Hamelers et al. 2002a), and PKB (Hamelers et al. 2002a). Taken together, it remains unclear whether E2 is a physiological activator of cytoplasmic signaling cascades and, if so, what the contribution of this activation might be for the mitogenic effect of the hormone.

\section{The IGF system in breast cancer}

The IGFs are a family of hormones with structural homologies to insulin (Rinderknecht \& Humbel 1976a,b). IGFs were discovered during the search for factors that mediate the growth-stimulating effect of growth hormone (Salmon \& Daughaday 1957). Further research revealed that two IGFs exist, IGF-I (70 amino acids long) and IGF-II (67 amino acids long) (Rinderknecht \& Humbel 1978a,b). IGF-I and -II play pivotal roles in growth and development. IGF-II is most important during fetal development, although the circulating level of IGF-II in humans (in contrast to rodents) remains high postnatally. The levels of IGF-I are low during fetal development and rise gradually after birth, indicating that this growth factor is mainly involved in postnatal growth (reviewed in Steenbergh et al. 1997). In all stages of life, a clear pattern of tissue-specific expression of IGFs is observed. Hepatocytes are the main source of circulating IGFs but, in addition, numerous non-hepatic tissues are capable of IGF synthesis. Many cells have been identified as producing as well as responding to the IGFs, including fibroblasts, chondrocytes, osteoblasts, granulosa cells, and epithelial breast cells (D'Ercole et al. 1984, Adashi et al. 1985, Han et al. 1987).
In order to exert their action, IGFs bind to membraneassociated receptors and thus activate multiple cytoplasmic signaling cascades involved in the transduction of the mitogenic and anti-apoptotic signal to the nucleus of the cell. An overview of the IGF signaling system and the molecules modulating the actions of this system are depicted in Fig. 2. Two main types of IGF receptors have been described. The IGF type II receptor (IGF-RII) exclusively binds IGF-II. The IGF-RII, which is also the cation-independent mannose-6phosphate receptor, is a $300 \mathrm{kDa}$ protein with a large extracellular domain and a small intracellular domain. The IGFRII does not have tyrosine kinase activity and its ability to transduce signals is not clear. It is thought that it is important for the sequestration of IGF-II, thus preventing the interaction of IGF-II with the IGF type I receptor (IGF-RI) (Ellis et al. 1996). The IGF-RII is also involved in targeting proteins to the lysosomes and may play a role in degradation of the extracellular matrix (reviewed in Sachdev \& Yee 2001).

The IGF-RI binds both IGF-I and IGF-II, although IGF-I binding is stronger than IGF-II binding. Most of the physiological effects of the IGFs are mediated by the type I receptor (Leroith et al. 1995). The IGF-RI is expressed ubiquitously in human tissues with the exception of hepatocytes and T-lymphocytes (reviewed in Sachdev \& Yee 2001). The IGF-RI is transcribed from a single gene as a precursor that is then processed into an $\alpha$ - and a $\beta$-subunit (Ullrich et al. 1986). The functional receptor is heterotetrameric consisting of two $\alpha$-subunits and two $\beta$-subunits, which are linked by two disulfide bonds. The $\alpha$-subunits are extracellular and form the ligand-binding domain. The $\beta$-subunits, which contain a short extracellular and transmembrane segments and a larger intracellular segment, transmit the ligand-induced signal. Activation of the IGF-RI by ligand binding leads to a conformational change in the receptor, auto-phosphorylation of tyrosine residues in the intracellular $\beta$-subunits of the receptor and subsequent activation of downstream signaling molecules. The $\beta$-subunits are known to bind signaling adaptor proteins like insulin receptor substrate (IRS)-1 and Shc, linking the receptor to downstream signaling pathways like the PI3-kinase and the ERK pathway (reviewed in Surmacz et al. 1998).

The IGF-binding proteins (IGFBPs) play a modulating role by regulating receptor-ligand interactions in the IGF system. The IGFBP family comprises six proteins with high affinity for the IGFs (IGFBP) and several lower affinity IGFBP-related proteins (IGFBP-rP). The binding of IGFBPs to IGF-I and IGF-II inhibits the mitogenic effects of the IGFs by restricting binding of these ligands to their receptor. The IGFBPs also regulate IGF bioavailability by maintaining a circulating reservoir of IGFs, and by prolonging their halflife. In addition to the regulatory effects of IGFBPs on IGF signaling, there is increasing evidence for autonomous effects, independent of IGF, in a number of tissues. How these autonomous effects are mediated is not yet clear, although a putative receptor for IGFBP-3 and -5 has been 
High-affinity IGF binders

IGFBP-1 IGFBP-2 IGFBP-3 IGFBP-4 IGFBP-5 IGFBP-6
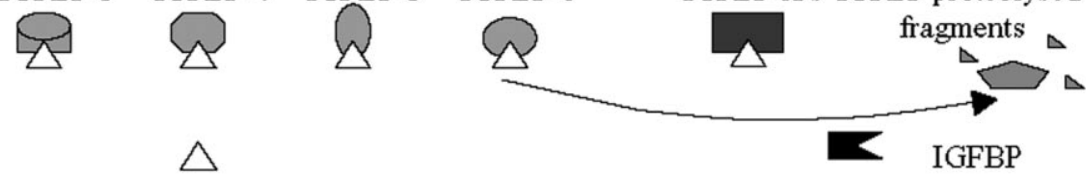

protease

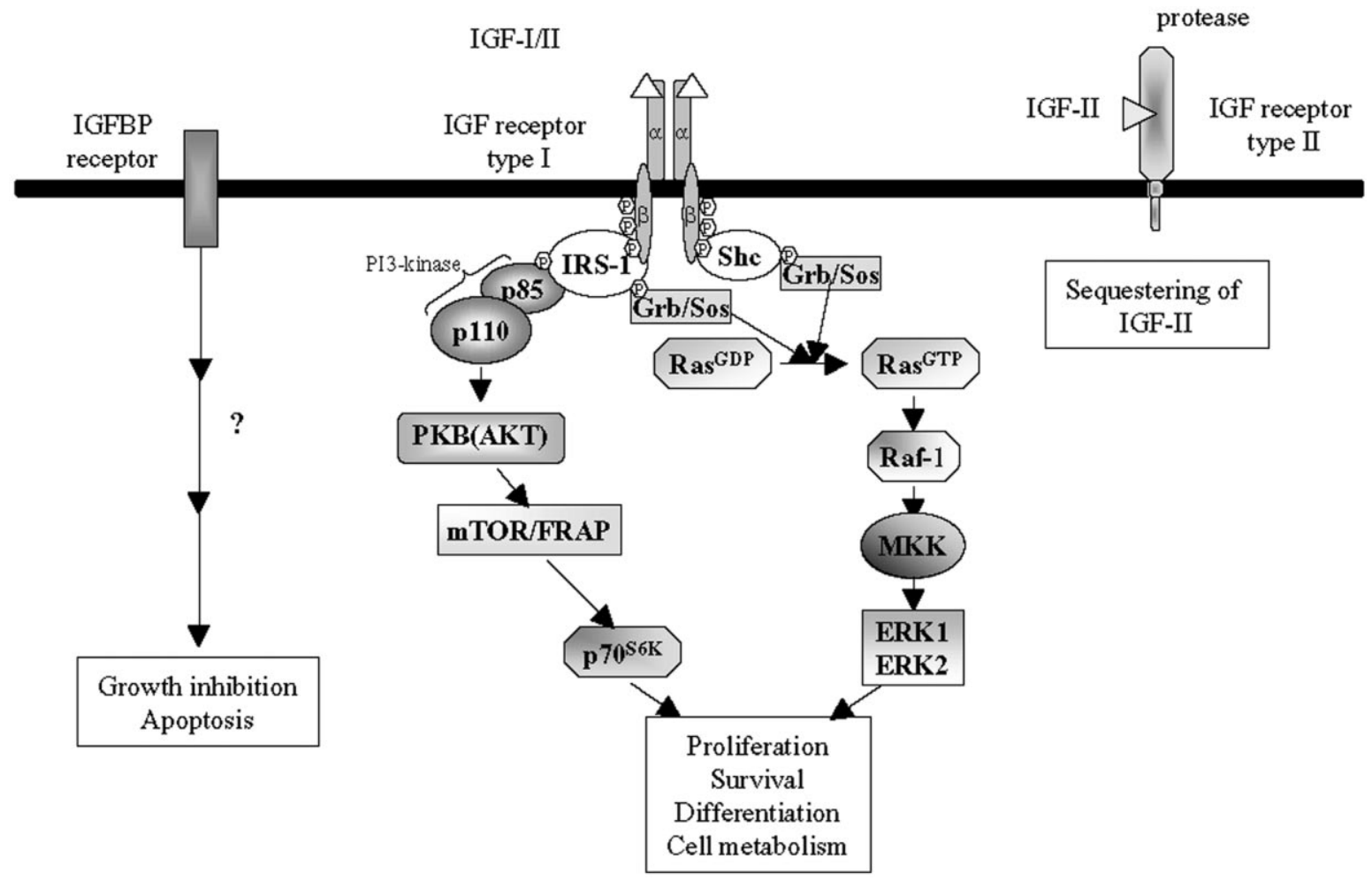

Figure 2 General outline of the IGF system and its downstream effectors. IGFBP, IGF-binding protein; IGFBP-rP, IGFBP-related proteins. mTor, target of rapamycin; FRAP, FkBP-rapamycin associated protein; MKK, MAP kinase kinase.

described (reviewed in Hwa et al. 1999). A number of observations indicate that IGFBPs may be involved in regulation of apoptosis and growth inhibition (reviewed in Perks \& Holly 2000). The expression of IGFBPs is regulated at the transcriptional level by steroid hormones, growth factors and cytokines. Post-translational modifications like phosphorylation, glycosylation and proteolytic cleavage have been shown to be involved in the regulation of IGFBP function (reviewed in Clemmons 1997).

In the breast, IGF-I is expressed in stromal cells adjacent to normal epithelial cells. IGF-II is not expressed in the normal breast and, thus far, the role for IGF-II in normal breast development is not clear (Paik 1992). However, many reports have identified IGFs as key regulators of growth in human breast cancer. IGF-I, IGF-II, and insulin (at supraphysiological concentrations) have been reported to stimulate growth of breast cancer cell lines (Van der Burg et al. 1988, Osborne et al. 1990, Musgrove \& Sutherland 1993, Dufourny et al. 2000,
Bartucci et al. 2001). In addition, breast tumors have been shown to overexpress many components of the IGF system (reviewed in Lee et al. 1998) and the role of IGF signaling in breast tumors has been confirmed by different strategies interfering with receptor function. These studies have shown inhibition of proliferation of breast cancer cell lines in vitro and inhibition of growth of tumor xenografts in nude mice (reviewed in Lee et al. 1998, Surmacz et al. 1998). If the IGFs play a critical role in the development of human breast cancer, their expression should be a predictor of the prognosis of the disease. Unfortunately, due to the complexity of the system, measurement of a single component of the system may not give a meaningful result, and analysis of a number of the key components will need to be performed.

A number of studies have shown that circulating levels of IGF-I are elevated in breast cancer patients compared with age-matched controls (Peyrat et al. 1993), and that either removal of the tumor or treatment with anti-estrogens lowers 
circulating IGF-I levels (reviewed in Pollak et al. 1992). It is tempting to speculate that endocrine IGF-I may be responsible for tumor growth. However, there are no direct data supporting this hypothesis. In breast cancer patients with significantly higher circulating IGF-I levels, no correlation has been found with several prognostic values such as ER expression or nodal status (Barni et al. 1994). Measurement of IGF-I levels in advanced stage breast cancer patients has not revealed any correlation with short-term survival (Bhatavdekar et al. 1994).

Only a few studies have directly examined the expression of IGFs in breast tumors. In these studies, IGF-I and -II expression in breast tumor tissue has been measured either by enzyme-linked immunosorbent assay on cytosolic fractions of the tumor (Yu et al. 1996), or by immunohistochemistry on tumor tissue sections (Toropainen et al. 1995a,b). $\mathrm{Yu}$ et al. (1996) have demonstrated that IGF-I expression does not correlate with other prognostic markers, whereas the data of Toropainen et al. (1995a) suggest that IGF-I expression is related to malignant histopathological features in breast cancer. Toropainen et al. (1995a) have further shown that expression of IGF-I has independent prognostic significance in the early phases of the breast cancer. Both groups (Toropainen et al. 1995b, Yu et al. 1996) have found that the expression of IGF-II in the tumor was weakly inversely related with poor prognostic features like tumor grade, high percentage of cells in $\mathrm{S}$ phase, and aneuploidy.

IGF-RI is often found to be overexpressed in breast carcinomas with respect to its status in normal breast epithelium or in benign tumors (reviewed in Surmacz et al. 1998), although the IGF-RI gene copy is rarely amplified (Berns et al. 1992). Expression of the IGF-RI has been shown to correlate with a better prognosis both in relapse-free survival and overall survival of breast cancer patients (Papa et al. 1993). The positive prognosis for patients in whom the tumor expresses high levels of IGF-RI is in conflict with the majority of in vitro studies supporting a role for the receptor in transformation and malignancy. Some studies (Arteaga 1992, Brunner et al. 1993) have demonstrated that a blockade of the IGF-RI with an anti-IGF-RI antibody inhibits the proliferation of breast tumor cell lines in vitro and the growth of tumor xenografts in nude mice. The reason for the favorable prognostic value of the IGF-RI expression by breast tumors may be similar to that for ER $\alpha$ expression. Also here, expression of the receptor may reflect well-differentiated tumors that still require IGF for proliferation (Beckmann et al. 1997), and are thus sensitive to anti-IGF therapy.

In ER-positive breast cancer cell lines, one of the major effectors of the activated IGF-RI is IRS-1 (Surmacz 2000). In ER-negative cell lines, IRS-2 instead of IRS-1 seems to be the major effector of the IGF-RI (reviewed in Sachdev \& Yee 2001). Both IRS-1 and IRS-2 become phosphorylated upon binding to the activated IGF-RI, and serve to connect the receptor to multiple downstream pathways (reviewed in Surmacz et al. 1998). Although both ERK and PI3-kinase pathways are activated following IGF-I stimulation of the ER-positive MCF-7 breast cancer cell line, only the PI3kinase cascade signal is required for the transduction of the mitogenic signal. Activation of the PI3-kinase pathway leads to elevation of cyclin D1 levels and subsequent cell cycle progression (Dufourny et al. 1997). IRS-1 is overexpressed in some primary breast tumors, and from studies in breast tumor cell lines it has become clear that overexpression of IRS-1 makes the cells estrogen independent (Surmacz \& Burgaud 1995). Moreover, it has been shown that high levels of IRS-1 in tumors correlate with a higher recurrence rate (Rocha et al. 1997). This suggests that IRS-1-mediated signaling in breast cancer cells could be involved in the development and progression of breast cancer.

The expression and activity of IGFBPs is regulated by a complex system in mammary epithelium involving steroid hormones (estrogen and progesterone) (Figueroa et al. 1993) and polypeptide hormone regulators (TGF $\beta$ ) (Oh et al. 1995). Clinical data presented to date have provided ambiguous evidence as to whether the IGFBPs, in particular IGFBP-3, predict a good or bad prognosis for breast cancer. One study has indicated that increased IGFBP-3 levels correlate with a number of features that predict an unfavorable outcome, e.g. larger tumor size and aneuploidy (Rocha et al. 1996). However, a second study examining disease recurrence or disease-free survival has found no significant correlation with IGFBP-3 expression levels (Rocha et al. 1997). In addition, recent studies have indicated that a low IGFBP-3 concentration in combination with a high IGF-I level in the blood circulation predicts a high risk of breast cancer development (Hankinson et al. 1998). This observation reinforces the notion that the balance in the expression of proteins of the IGF system may be an important factor in the prediction of cancer risk and prognosis.

\section{Cross-talk between the IGF and E2 signaling pathway}

Thus far, only the effects of single hormones on the regulation of breast cancer growth have been discussed. The idea that a single growth factor or hormone determines cell growth has been proven false in virtually every system examined. Over the last decade, accumulating evidence for interactions between estrogen and IGF signaling pathways has been reported. Four distinct ways of interaction can be distinguished, which will be discussed below. The first type of interaction has been documented by a number of reports showing long-term regulation of expression of proteins of the IGF system by E2. The second type of interaction is a more rapid one, indicating direct activation of the IGF-RI by the liganded ER. A third type of interaction between IGF and E2 signaling pathways has been described in several reports showing transcriptional activation of the ER by IGF signaling. Finally, several groups have reported synergistic 
effects of the two hormones on the expression and activation of cell cycle components, leading to enhanced proliferation rates.

\section{E2-regulated expression components of the IGF-I system}

The long-term effects of E2 on the IGF system have been studied extensively. E2 appears to interact with the IGF system and signaling route at several points. The expression of IGF-RI, IRS-1, and IGFBPs have been shown to be upregulated by E2 (Huynh et al. 1996, Lee et al. 1999, Molloy et al. 2000, Perks \& Holly 2000). A number of reports show that E2 enhances the synthesis of both IGFs in malignant breast epithelial cell lines. Huff et al. (1988) and Cohen et al. (1990) report IGF-I mRNA and protein expression in MCF-7 cells, which is upregulated by E2, insulin, TGF $\alpha$, and EGF. Other groups have reported that MCF-7 cells do not express IGF-I (Yee et al. 1989, Van der Burg et al. 1990, Gebauer et al. 1998). Thus far, no explanation for the inconsistency in the experimental results on IGF-I expression has been found, and it remains unclear whether breast cancer cells secrete IGF-I.

Osborne et al. (1989) have detected expression of IGF-II in T47D and MCF-7 cells, with highest expression of IGF-II in T47D. However, Van der Burg et al. (1990) and Gebauer et al. (1998) failed to detect IGF-II secretion by MCF-7 breast cancinoma cells. The discrepancies in the results on IGF-II expression in breast cancer cell lines may be explained by the observation that IGF-II expression in MCF-7 cells could only be detected in late passage subclones of MCF-7. In early passages (up to passage 40) of the MCF-7 cell line, Yee et al. (1988) did not detect any IGF-II mRNA in an RNase protection assay.

\section{Rapid effects of E2 on the IGF signaling pathway}

An unexpected link between the estrogen and IGF signaling pathways has been demonstrated in a study by Kahlert et al. (2000). They transfected ER $\alpha$ or ER $\beta$ in COS7 and HEK293 cells, which both express IGF-RI. In the presence of ER $\alpha$, but not ER $\beta$, E2 rapidly induced phosphorylation of the IGF-RI and ERK-1 and -2. Furthermore, upon stimulation with $\mathrm{E} 2, \mathrm{ER} \alpha$, but not $\mathrm{ER} \beta$, bound rapidly to the IGF-RI in COS7. The interaction of the ER $\alpha$ and the IGF-RI is also observed in L6 cells, which express ER $\alpha$ and IGF-RI endogenously. Control experiments in the IGF-RI-deficient fibroblast cell line $\mathrm{R}$ - showed that only $\mathrm{ER} \alpha$ binds to the transfected IGF-RI after stimulation with E2. Overexpression of dominant negative mitogen-activated protein kinase kinase inhibits this effect. Finally, these authors demonstrate that $\mathrm{ER} \alpha$, but not $\mathrm{ER} \beta$, is required to induce the activation of the estrogen receptor-responsive luciferase reporter (ERE-LUC) in IGF-I-stimulated cells. Taken together, these data have demonstrated that ligand-bound ER is required for rapid activation of the IGF-RI signaling cascade. If the activation also occurs in human breast cancer cells, treatment of $\mathrm{MCF}-7$ cells with E2 would be expected to lead to a strong activation of the IGF-RI/PI3-kinase pathway. However, in the MCF-7S model system used in our laboratory, we have not been able to demonstrate the interaction of the ER $\alpha$ and IGF-RI, or activation of the ERK and PI3-kinase pathways in E2stimulated MCF-7S cells (Hamelers et al. 2002a).

\section{Rapid effects of IGF on the activation of the E2 receptor (ER)}

IGFs have been implicated in the regulation of the activity of the ER by a number of observations. Several studies have demonstrated that IGFs as well as other growth factors activate the (unliganded) ER (Kato et al. 1995, Lee et al. 1997, Ram et al. 1998, Stoica et al. 2000, Campbell et al. 2001). Co-administration of E2 and growth factors to cells has been shown to result in an additive effect on the expression of endogenous estrogen-regulated genes (Stoica et al. 2000).

Kato et al. (1995) have shown that the human ER $\alpha$ is phosphorylated by ERK on $\operatorname{Ser}^{18}$ within 15 min after the addition of EGF and IGF-I to the cells in vitro. The phosphorylation of this serine is required for full activity of the $\mathrm{ER} \alpha \mathrm{AF}-1$ domain. Overexpression of active ERK kinase (MEK) or of the active $\mathrm{p} 21^{\text {ras }}$, both of which activate ERK, enhances estrogen-induced transcriptional activity of the wild-type $\mathrm{ER} \alpha$, but not of a mutant $\mathrm{ER} \alpha$ with an alanine in place of $\operatorname{Ser}^{118}$ (Kato et al. 1995). More recently, Endoh et al. (1999) have identified a coactivator associating with the human ER $\alpha \mathrm{AF}-1$ in an ERK-mediated, phosphorylationdependent manner. They have shown that the interaction of the p68 coactivator with the A/B domain is essential for the full activation of the human $\mathrm{ER} \alpha \mathrm{AF}-1$.

PI3-kinase, which is activated by IGF-I and other growth factors, has been shown to phosphorylate the $\operatorname{ER} \alpha$ within 1 $h$ after addition of the activating stimulus. Active PI3-kinase increases the transcription-stimulating activity of both the $\mathrm{AF}-1$ and AF-2 domains of ER $\alpha$, whereas active PKB only increases the activity of AF-1. Phosphatase and tensin homologue PTEN, the phosphatase responsible for inactivation of PI3-kinase, and a catalytically inactive PKB decreased PI3-kinase-induced AF-1 activity, suggesting that PI3-kinase utilizes PKB-dependent and PKB-independent pathways in activating ER $\alpha$. The consensus PKB phosphorylation site at $\operatorname{Ser}^{167}$ of ER $\alpha$ is required for activation by PKB. In addition, LY294002, a specific inhibitor of the PI3-kinase/PKB pathway, reduced phosphorylation of $\mathrm{ER} \alpha$ in vivo (Campbell et al. 2001). 


\section{The combined mutual reinforcing effects of IGF-I and E2 on cell cycle regulation}

Both IGF-I and E2 have been shown to synergistically stimulate proliferation of various tissues and cultured cells, including breast tumor cells (Van der Burg et al. 1988, CardonaGomez et al. 2001). Several groups have tried to identify the pathways involved in the induction of a mitogenic response of breast cancer cells upon addition of the combination of E2 and submitogenic amounts of IGF-I. Thus far, two different models have been put forward to explain the synergy of IGF-I and E2. The first model, schematically depicted in Fig. 3, is based on the combined results of two laboratories (Dupont et al. 2000, Lai et al. 2001). In these experiments, MCF-7 cells were synchronized by anti-estrogen (ICI 182780) treatment. Both laboratories have shown that treatment of MCF-7 cells with E2 and IGF-I induces changes in the expression of cell cycle components, leading to activation of the cyclin E/cyclin-dependent kinase inhibitor (CDK)-2.

Lai et al. (2001) have shown that addition of IGF-I does not re-initiate cell cycle progression. This is in marked contrast to cells synchronized by serum starvation, in which the addition of $20 \mathrm{ng} / \mathrm{ml}$ IGF-I has been shown to induce cell cycle progression and cell proliferation (Dufourny et al.
1997). Furthermore, Lai and colleagues (2001) have shown that in MCF-7 cells synchronized with the ICI compound, IGF-I increases cyclin D1, cyclin E, and p2 $1^{\text {cipl/wafl }}$ gene expression and induces the formation of active CDK4 complexes. However, addition of IGF-I results in only minor increases in cyclin E-CDK2 activity. Treatment with E2 results in a larger increase in cyclin D1 gene expression than with IGF-I, and markedly decreases p21 $1^{\text {cipl/wafl }}$ expression, with a concurrent increase in CDK4 and CDK2 activity and subsequent synchronous entry of cells into $\mathrm{S}$ phase. Coadministration of IGF-I and E2 induces synergistic stimulation of $\mathrm{S}$ phase entry coincident with synergistic activation of cyclin E-CDK2 complexes lacking p21 $1^{\text {cipl/wafl }}$. To determine if the ability of E2 to deplete $\mathrm{p} 21^{\text {cipl/wafl }}$ was central to these effects, cells stimulated with insulin and E2 were infected with recombinant adenovirus expressing $\mathrm{p} 21^{\text {cipl/wafl }}$. Induction of $\mathrm{p} 21^{\text {cipl/wafl }}$ to levels equivalent to those following treatment with IGF-I alone markedly inhibits the synergism of E2 and IGF-I on S phase entry.

Dupont et al. (2000) have shown that MCF-7 cells synchronized with ICI 182780 are stimulated to proliferate by both IGF-I and E2 individually, and the addition of the combination of the mitogens resulted in a synergistic response.

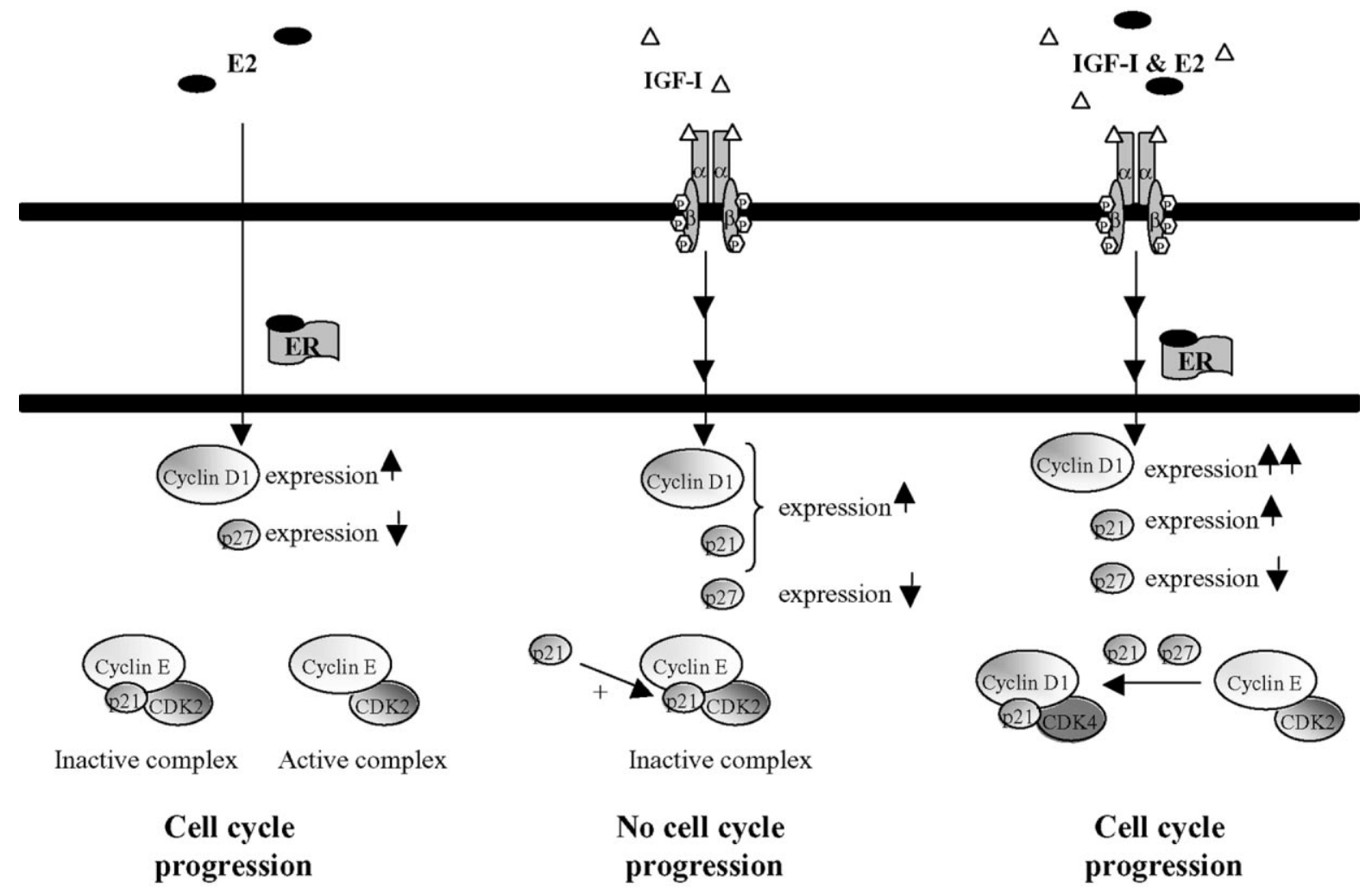

Figure 3 Model for the synergism of IGF-I and E2 in ICI 182780-synchronized cells. 
They demonstrated that E2 is also able to potentiate the IGF-I effect on the expression of cyclin D1 and cyclin E and on the phosphorylation of retinoblastoma protein. Stimulation with IGF-I increases the protein level of $\mathrm{p} 21^{\text {cipl/wafl }}$ and the transcriptional activity of the $\mathrm{p} 21^{\text {cipl/wafl }}$ promoter, whereas it reduces the protein level of $\mathrm{p} 27^{k i p l}$, without affecting $\mathrm{p} 27^{k i p l}$ promoter activity. E2 does not affect the expression of $\mathrm{p} 21^{\text {cipl/ }}$ wafl, but it decreases the protein level of $\mathrm{p} 27^{k i p l}$ and the $\mathrm{p} 27^{k i p l}$ promoter activity. The decreased expression of $\mathrm{p} 27^{k i p l}$ is accompanied by a decrease of $\mathrm{p} 27^{k i p l}$-associated CDK2. This suggests that IGF-I and E2 regulate the activity of CDK2 by regulating the expression of both $\mathrm{p} 21^{\text {cipl/wafl }}$ and $\mathrm{p} 27^{k i p l}$.

Taken together, these data suggest that, in MCF-7 cells, two distinct actions induced by IGF-I and E2 may be responsible for synergistic stimulation of cell proliferation of ICI 182780-synchronized MCF-7 cells by the two hormones. The first action involves sequestration of the cyclin-dependent kinase inhibitors (CKI) $\mathrm{p} 21^{\text {wafl/cipl }}$ and to a lesser extent $\mathrm{p} 27^{k i p l}$ in E2-induced cyclin D1/CDK4 complexes, and the second involves inhibition of $\mathrm{p} 21^{\text {wafl/cipl }}$ gene transcription. Both actions lead to formation of active cyclin E/CDK2 complexes lacking CKIs.

Based on our work in MCF-7S cells, we have proposed a different model for the synergistic effect of E2 and IGF-I in breast cancer (Hamelers et al. 2002a,b). In contrast to experiments on which the first model is based, our MCF-7S cells were synchronized by serum deprivation. IGF-I, in a concentration of $20 \mathrm{ng} / \mathrm{ml}$, is a potent mitogen in synchronized MCF-7S cells (Dufourny et al. 1997). A tenfold lower concentration (i.e. $2 \mathrm{ng} / \mathrm{ml}$ ) is by itself unable to trigger the mitogenic response (Hamelers et al. 2002a). We have demonstrated that $\mathrm{E} 2$, in concentrations ranging from 0.1 to 100 $\mathrm{nM}$, does not induce cell cycle progression in quiescent MCF-7S cells. However, the combination of submitogenic amounts of IGF-I $(2 \mathrm{ng} / \mathrm{ml})$ and E2 $(1 \mathrm{nM})$ synergistically induces cell cycle progression and proliferation. We have found that both E2 and mitogenic amounts of IGF-I induce cyclin D1 expression, whereas submitogenic amounts of IGF-I do not significantly elevate cyclin D1 levels. IGF-I, but not E2, is able to activate PI3-kinase, which leads to inhibition of glycogen synthase kinase $3 \beta$ (GSK3 $\beta$ ) activity. Here, a per se non-mitogenic amount of IGF-I suffices. Inhibition of GSK3 $\beta$ triggers nuclear accumulation of the cyclin D1, but only if cyclin D1 levels are strongly induced concomitantly. After cyclin D1 accumulates in the nucleus, activation of the cyclin D1-CDK4 complex and subsequent cell cycle progression is observed.

Based on these findings, we propose the model depicted in Fig. 4. Mitogenic amounts of IGF-I are proficient in inducing cyclin D1 and in inactivating GSK3 $\beta$. E2 may substitute for IGF-I in its ability to enhance cyclin D1 levels. Since a much lower concentration of IGF-I is sufficient to suppress GSK3 $\beta$ activity, even a submitogenic amount of
IGF-I in synergy with E2 is now able to trigger cell cycle progression in MCF-7S cells.

This model predicts that IGF-I may be replaced by an inhibitor of GSK3 $\beta$. Recently, we have demonstrated that E2 in the presence of $\mathrm{LiCl}$, a well-documented inhibitor of GSK3 $\beta$, induces nuclear accumulation of cyclin D1, CDK2 activation, hyperphosphorylation of retinoblastoma protein and DNA synthesis, without the need of co-administration of IGF-I (Hamelers et al. 2002b). This confirms that IGF-Iinduced GSK3 $\beta$ inactivation is an essential step in the regulation of subcellular localization of cyclin D1 during G1 phase.

According to this model, E2 cannot by itself induce proliferation of $\mathrm{MCF}-7$ breast cancer cells without the additional IGF-I signal. This holds true for MCF-7S, but other MCF-7 laboratory strains seemingly proliferate upon E2 stimulation. However, IGF signaling still seems to be required since E2induced cell proliferation of these strains is blocked by preincubation with the IGF-RI blocking antibody, $\alpha$ IR3 (author's unpublished observation) and by an inhibitor of the PI3kinase pathway, LY 294002 (author's unpublished data). Moreover, E2 responsiveness could be transferred by incubating E2-unresponsive cells in conditioned medium of E2sensitive cells. This suggests that E2-sensitive MCF-7 strains secrete a factor which supplies the required IGF-RIdependent signal by an autocrine mechanism.

\section{Conclusion}

In this review we have examined the mechanisms by which E2 and IGFs regulate breast cancer cell proliferation. E2, via activation of the ER, enhances the expression of growthrelated genes, one of the most noteworthy being cyclin D1. In addition, E2 may regulate breast cancer cell growth via activation of signal transduction cascades, like the PI3-kinase and ERK pathways. However, the reports on the activation of non-genomic pathways by E2 are contradictory. More research is needed to establish whether E2 is a physiological activator of cytoplasmic signaling cascades and, if so, what the contribution of this activation might be to the mitogenic effect of the hormone.

IGF has been shown to induce proliferation in breast cancer cells as well. The IGF signal is transduced by the activation of the tyrosine kinase receptor IGF-RI. Subsequently, the ERK and the PI3-kinase pathway are activated, although only the activation of the PI3-kinase pathway has been shown to be essential in mediating the growth signal.

At lower, submitogenic concentrations, IGF is still able to trigger the proliferative signal in breast cancer cells in concert with E2. If one of the receptors is blocked, e.g. the ER by the anti-estrogen ICI $182\{\}$.780 or the IGF-RI by the antibody $\alpha$ IR3, the proliferative response is suppressed. This may well indicate the need for both hormonal signals to induce breast cancer cell growth when E2 and IGF are 


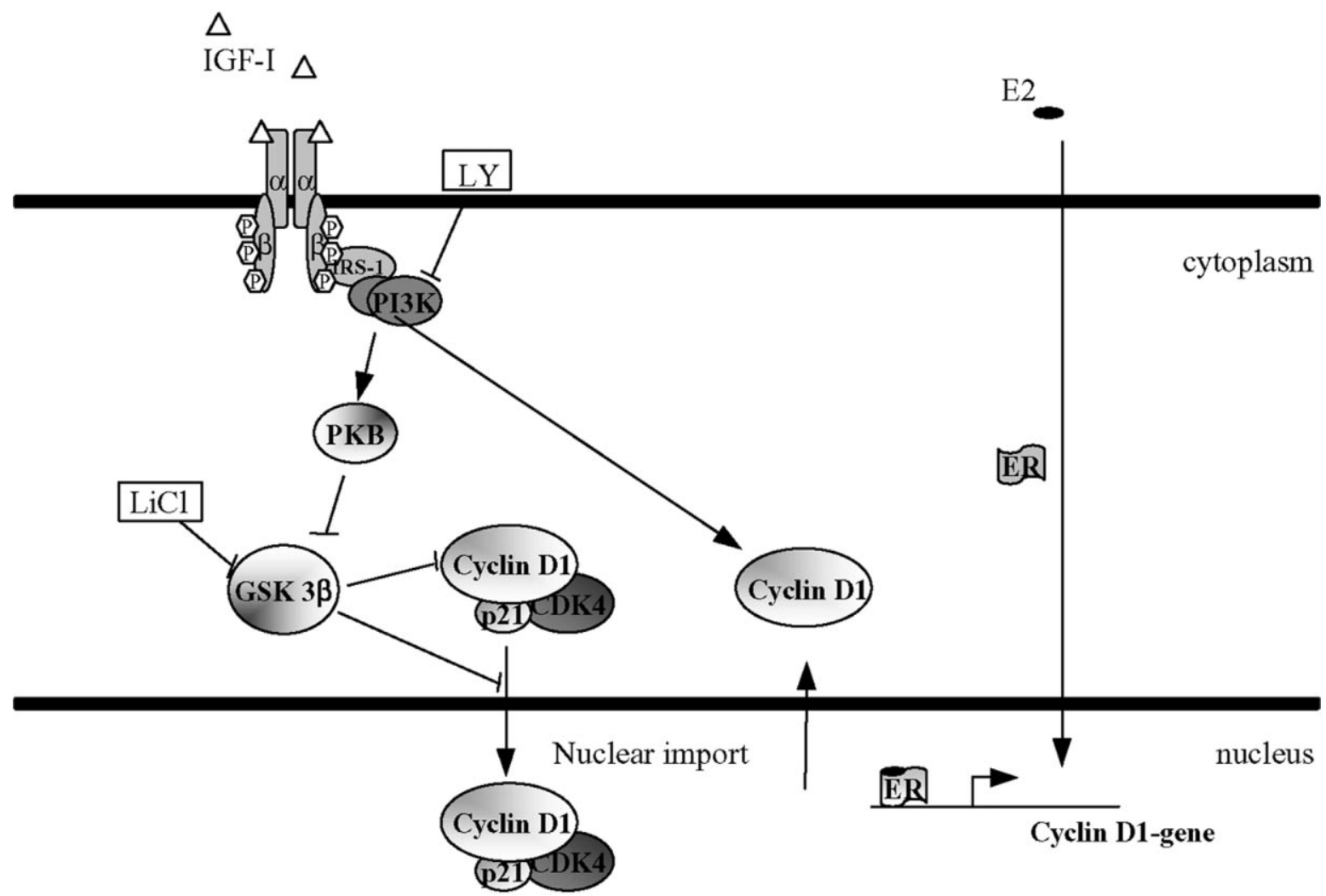

Figure 4 Model for the synergism of IGF-I and E2 in serum-starved cells. PI3K, PI3-kinase. LY, LY 294002.

present at physiological concentrations. As a logical consequence, it may be of great advantage to consider a combinational therapy of anti-IGF and anti-E2 treatment for breast cancer. This combination may provide a more effective way to treat breast tumors and may even prevent tumor progression.

\section{References}

Adashi EY, Resnick CE, D’Ercole AJ, Svoboda ME \&Van Wyk JJ 1985 Insulin-like growth factors as intraovarian regulators of granulosa cell growth and function. Endocrine Reviews 6400 420.

Adler S, Waterman ML, He X \& Rosenfeld MG 1988 Steroid receptor-mediated inhibition of rat prolactin gene expression does not require the receptor DNA-binding domain. Cell $\mathbf{5 2}$ 685-695.

Ahmad S, Singh N \& Glazer RI 1999 Role of AKT1 in $17 \beta$-estradiol- and insulin-like growth factor I (IGF-I)-dependent proliferation and prevention of apoptosis in MCF-7 breast carcinoma cells. Biochemical Pharmacology 58 425-430.

Altucci L, Addeo R, Cicatiello L, Dauvois S, Parker MG, Truss M, Beato M, Sica V, Bresciani F \& Weisz A 1996 17ß-Estradiol induces cyclin D1 gene transcription, $\mathrm{p} 36^{\mathrm{Dl}} \mathrm{p} 34^{\text {cdk4 }}$ complex activation and $\mathrm{p} 105^{\mathrm{Rb}}$ phosphorylation during mitogenic stimulation of $\mathrm{G}_{1}$-arrested human breast cancer. Oncogene $\mathbf{1 2}$ 2315-2324.
Arteaga CL 1992 Interference of the IGF system as a strategy to inhibit breast cancer growth. Breast Cancer Research and Treatment 22 101-106.

Barni S, Lissoni P, Brivio F, Fumagalli L, Merlini D, Cataldo M, Rovelli F \& Tancini G 1994 Serum levels of insulin-like growth factor-I in operable breast cancer in relation to the main prognostic variables and their perioperative changes in relation to those of prolactin. Tumori $80212-215$.

Bartucci M, Morelli C, Mauro L, Ando’ S \& Surmacz E 2001 Differential insulin-like growth factor I receptor signaling and function in estrogen receptor (ER)-positive MCF-7 and ER-negative MDA-MB-231 breast cancer cells. Cancer Research $616747-6754$.

Beato M \& Klug J 2000 Steroid hormone receptors: an update. Human Reproduction Update 6 225-236.

Beato M, Herrlich P \& Schutz G 1995 Steroid hormone receptors: many actors in search of a plot. Cell 83 851-857.

Beckmann MW, Niederacher D, Schnurch HG, Gusterson BA \& Bender HG 1997 Multistep carcinogenesis of breast cancer and tumour heterogeneity. Journal of Molecular Medicine 75 429439.

Berns EM, Klijn JG, van Staveren IL, Portengen H \& Foekens JA 1992 Sporadic amplification of the insulin-like growth factor 1 receptor gene in human breast tumors. Cancer Research $\mathbf{5 2}$ 1036-1039.

Bhatavdekar JM, Patel DD, Karelia NH, Vora HH, Ghosh N, Shah NG, Balar DB \& Trivedi SN 1994 Tumor markers in patients with advanced breast cancer as prognosticators: a preliminary study. Breast Cancer Research and Treatment 30 293-297. 
Biscardi JS, Ishizawar RC, Silva CM \& Parsons SJ 2000 Tyrosine kinase signalling in breast cancer: epidermal growth factor receptor and c-Src interactions in breast cancer. Breast Cancer Research 2 203-210.

Blackburn AC \& Jerry DJ 2002 Knockout and transgenic mice of Trp53: what have we learned about p53 in breast cancer? Breast Cancer Research 4 101-111.

Borellini F \& Oka T 1989 Growth control and differentiation in mammary epithelial cells. Environmental Health Perspectives $\mathbf{8 0}$ 85-99.

Brunner N, Yee D, Kern FG, Spang-Thomsen M, Lippman ME \& Cullen KJ 1993 Effect of endocrine therapy on growth of T61 human breast cancer xenografts is directly correlated to a specific down-regulation of insulin-like growth factor II (IGF-II). European Journal of Cancer 29A 562-569.

Campbell RA, Bhat-Nakshatri P, Patel NM, Constantinidou D, Ali S \& Nakshatri H 2001 Phosphatidylinositol 3-kinase/ AKT-mediated activation of estrogen receptor alpha: a new model for anti-estrogen resistance. Journal of Biological Chemistry 276 9817-9824.

Cardona-Gomez GP, Mendez P, DonCarlos LL, Azcoitia I \& Garcia-Segura LM 2001 Interactions of estrogens and insulin-like growth factor-I in the brain: implications for neuroprotection. Brain Research Reviews 37 320-334.

Caristi S, Galera JL, Matarese F, Imai M, Caporali S, Cancemi M, Altucci L, Cicatiello L, Teti D, Bresciani F \& Weisz A 2001 Estrogens do not modify MAP kinase-dependent nuclear signaling during stimulation of early G(1) progression in human breast cancer cells. Cancer Research 61 6360-6366.

Castoria G, Barone MV, Di Domenico M, Bilancio A, Ametrano D, Migliaccio A \& Auricchio F 1999 Non-transcriptional action of oestradiol and progestin triggers DNA synthesis. EMBO Journal 18 2500-2510.

Castoria G, Migliaccio A, Bilancio A, Di Domenico M, de Falco A, Lombardi M, Fiorentino R, Varricchio L, Barone MV \& Auricchio F 2001 PI3-kinase in concert with Src promotes the S-phase entry of oestradiol-stimulated MCF-7 cells. EMBO Journal 20 6050-6059.

Clarke R, Brunner N, Katzenellenbogen BS, Thompson EW, Norman MJ, Koppi C, Paik S, Lippman ME \& Dickson RB 1989 Progression of human breast cancer cells from hormone-dependent to hormone-independent growth both in vitro and in vivo. PNAS 86 3649-3653.

Clemmons DR 1997 Insulin-like growth factor binding proteins and their role in controlling IGF actions. Cytokine and Growth Factor Reviews 8 45-62.

Cohen FJ, Manni A, Glikman P, Bartholomew M \& Demers L 1990 Interactions between growth factor secretion and polyamines in MCF-7 breast cancer cells. European Journal of Cancer 26 603-608.

Couse JF \& Korach KS 1999 Estrogen receptor null mice: what have we learned and where will they lead us? Endocrine Reviews 20 358-417.

Cowley SM \& Parker MG 1999 A comparison of transcriptional activation by ER alpha and ER beta. Journal of Steroid Biochemistry and Molecular Biology 69 165-175.

Daniel CW, Silberstein GB \& Strickland P 1987 Direct action of 17 beta-estradiol on mouse mammary ducts analyzed by sustained release implants and steroid autoradiography. Cancer Research 47 6052-6057.

D'Ercole AJ, Stiles AD \& Underwood LE 1984 Tissue concentrations of somatomedin C: further evidence for multiple sites of synthesis and paracrine or autocrine mechanisms of action. PNAS 81 935-939.

Dufourny B, Alblas J, Van Teeffelen HAAM, Van Schaik FMA, Van der Burg B, Steenbergh PH \& Sussenbach JS 1997 Mitogenic signaling of insulin-like growth factor I in MCF- 7 human breast cancer cells requires phosphatidylinositol 3-kinase and is independent of mitogen-activated protein kinase. Journal of Biological Chemistry 272 31163-31171.

Dufourny B, Van Teeffelen HAAM, Hamelers IHL, Sussenbach JS \& Steenbergh PH 2000 Stabilization of cyclin D1 mRNA via the phosphatidylinositol 3-kinase pathway in MCF-7 human breast cancer cells. Journal of Endocrinology 166 329-338.

Dupont J, Karas M \& Leroith D 2000 The potentiation of estrogen on insulin-like growth factor I action in MCF-7 human breast cancer cells includes cell cycle components. Journal of Biological Chemistry 275 35893-35901.

Early Breast Cancer Trialists Collaborative Group 1992 Systemic treatment of early breast cancer by hormonal, cytotoxic, or immune therapy. 133 randomised trials involving 31,000 recurrences and 24,000 deaths among 75,000 women. Lancet 339 71-85.

Ellis MJC, Leav BA, Yang ZJ, Rasmussen A, Pearce A, Zweibel JA, Lippman ME \& Cullen KJ 1996 Affinity for the insulin-like growth factor-II (IGF-II) receptor inhibits autocrine IGF-II activity in MCF-7 breast cancer cells. Molecular Endocrinology 10 286-297.

Endoh H, Maruyama K, Masuhiro Y, Kobayashi Y, Goto M, Tai H, Yanagisawa J, Metzger D, Hashimoto S \& Kato S 1999 Purification and identification of p68 RNA helicase acting as a transcriptional coactivator specific for the activation function 1 of human estrogen receptor alpha. Molecular and Cellular Biology 19 5363-5372.

Fearon ER \& Vogelstein B 1990 A genetic model for colorectal tumorigenesis. Cell 61 759-767.

Ferguson AT \& Davidson NE 1997 Regulation of estrogen receptor alpha function in breast cancer. Critical Reviews in Oncogenesis 8 29-46.

Figueroa JA, Sharma J, Jackson JG, McDermott MJ, Hilsenbeck SG \& Yee D 1993 Recombinant insulin-like growth factor binding protein-1 inhibits IGF-I, serum, and estrogen-dependent growth of MCF-7 human breast cancer cells. Journal of Cellular Physiology 157 229-236.

Foster JS, Henley DC, Ahamed S \& Wimalasena J 2001 Estrogens and cell-cycle regulation in breast cancer. Trends in Endocrinology and Metabolism 12 320-327.

Garfinkel L, Boring CC \& Heath CW Jr 1994 Changing trends. An overview of breast cancer incidence and mortality. Cancer $\mathbf{7 4}$ 222-227.

Gebauer G, Jäger W \& Lang N 1998 mRNA expression of components of the insulin-like growth factor system in breast cancer cell lines, tissues, and metastatic breast cancer cells. Anticancer Research 18 1191-1195.

Green S, Walter P, Kumar V, Krust A, Bornert JM, Argos P \& Chambon P 1986 Human oestrogen receptor cDNA: sequence, expression and homology to v-erb-A. Nature 320 134-139.

Gronemeyer H 1991 Transcription activation by estrogen and progesterone receptors. Annual Review of Genetics 25 89-123.

Hamelers IHL, van Schaik RFMA, van Teeffelen HAAM, Sussenbach JS \& Steenbergh PH $2002 a$ Synergistic proliferative action of insulin-like growth factor I and 17 beta-estradiol in MCF-7S breast tumor cells. Experimental Cell Research 273 $107-117$. 
Hamelers IHL, van Schaik RFMA, Sipkema J, Sussenbach JS \& Steenbergh PH $2002 b$ Insulin-like growth factor I triggers nuclear accumulation of cyclin D1 in MCF-7S breast cancer cells. Journal of Biological Chemistry 277 47645-47652.

Han VK, D'Ercole AJ \& Lund PK 1987 Cellular localization of somatomedin (insulin-like growth factor) messenger RNA in the human fetus. Science 236 193-197.

Hankinson SE, Willett WC, Colditz GA, Hunter DJ, Michaud DS, Deroo B, Rosner B, Speizer FE \& Pollak M 1998 Circulating concentrations of insulin-like growth factor-I and risk of breast cancer. Lancet 351 1393-1396.

Harris JR, Lippman ME, Veronesi U \& Willett W 1992 Breast cancer (3). New England Journal of Medicine 327 473-480.

Henderson IC 1993 Risk factors for breast cancer development. Cancer 71 2127-2140.

Henson DE \& Tarone RE 1994 Involution and the etiology of breast cancer. Cancer $\mathbf{7 4}$ 424-429.

Huff KK, Kaufman D, Gabbay KH, Spencer EM, Lippman ME \& Dickson RB 1986 Secretion of an insulin-like growth factor-I-related protein by human breast cancer cells. Cancer Research 46 4613-4619.

Huynh H, Nickerson T, Pollak M \& Yang X 1996 Regulation of insulin-like growth factor I receptor expression by the pure antiestrogen ICI 182780. Clinical Cancer Research 2 20372042.

Hwa V, Oh Y \& Rosenfeld RG 1999 The insulin-like growth factor-binding protein (IGFBP) superfamily. Endocrine Reviews 20 761-787.

Improta-Brears T, Whorton AR, Codazzi F, York JD, Meyer T \& McDonnell DP 1999 Estrogen-induced activation of mitogen-activated protein kinase requires mobilization of intracellular calcium. PNAS 96 4686-4691.

Iwao K, Miyoshi Y, Egawa C, Ikeda N \& Noguchi S 2000 Quantitative analysis of estrogen receptor-beta mRNA and its variants in human breast cancers. International Journal of Cancer 88 733-736.

Kahlert S, Nuedling S, van Eickels M, Vetter H, Meyer R \& Grohe C 2000 Estrogen receptor alpha rapidly activates the IGF-1 receptor pathway. Journal of Biological Chemistry 275 18447-18453.

Kato S, Endoh H, Masuhiro Y, Kitamoto T, Uchiyama S, Sasaki H, Masushige S, Gotoh Y, Nishida E, Kawashima H, Metzger D \& Chambon P 1995 Activation of the estrogen receptor through phosphorylation by mitogen-activated protein kinase. Science 270 1491-1494.

Kelley ST \& Thackray VG 1999 Phylogenetic analyses reveal ancient duplication of estrogen receptor isoforms. Journal of Molecular Evolution 49 609-614.

Kinsinger LS, Harris R, Woolf SH, Sox HC \& Lohr KN 2002 Chemoprevention of breast cancer: a summary of the evidence for the U.S. Preventive Services Task Force. Annals of Internal Medicine 137 59-69.

Korach KS 1994 Insights from the study of animals lacking functional estrogen receptor. Science 266 1524-1527.

Krege JH, Hodgin JB, Couse JF, Enmark E, Warner M, Mahler JF, Sar M, Korach KS, Gustafsson JA \& Smithies O 1998 Generation and reproductive phenotypes of mice lacking estrogen receptor beta. PNAS 95 15677-15682.

Kuiper GG, Enmark E, Pelto-Huikko M, Nilsson S \& Gustafsson JA 1996 Cloning of a novel receptor expressed in rat prostate and ovary. PNAS 93 5925-5930.
Lai A, Sarcevic B, Prall OW \& Sutherland RL 2001 Insulin/ insulin-like growth factor-I and estrogen cooperate to stimulate cyclin E-Cdk2 activation and cell cycle progression in MCF-7 breast cancer cells through differential regulation of cyclin $\mathrm{E}$ and p21(WAF1/Cip1). Journal of Biological Chemistry $27625823-$ 25833.

Lapidus RG, Nass SJ \& Davidson NE 1998 The loss of estrogen and progesterone receptor gene expression in human breast cancer. Journal of Mammary Gland Biology and Neoplasia 3 $85-94$.

Lazennec G, Bresson D, Lucas A, Chauveau C \& Vignon F 2001 ER beta inhibits proliferation and invasion of breast cancer cells. Endocrinology 142 4120-4130.

Lee AV, Weng CN, Jackson JG \& Yee D 1997 Activation of estrogen receptor-mediated gene transcription by IGF-I in human breast cancer cells. Journal of Endocrinology 152 39-47.

Lee AV, Hilsenbeck SG \& Yee D 1998 IGF system components as prognostic markers in breast cancer. Breast Cancer Research and Treatment 47 295-302.

Lee AV, Jackson JG, Gooch JL, Hilsenbeck SG, Coronado-Heinsohn E, Osborne CK \& Yee D 1999 Enhancement of insulin-like growth factor signaling in human breast cancer: estrogen regulation of insulin receptor substrate-1 expression in vitro and in vivo. Molecular Endocrinology 13 787-796.

Leroith D, Werner H, Beitner-Johnson D \& Roberts CT Jr 1995 Molecular and cellular aspects of the insulin-like growth factor I receptor. Endocrine Reviews 16 143-163.

Lobenhofer EK, Huper G, Iglehart JD \& Marks JR 2000 Inhibition of mitogen-activated protein kinase and phosphatidylinositol 3-kinase activity in MCF-7 cells prevents estrogen-induced mitogenesis. Cell Growth and Differentiation 11 99-110.

Loose-Mitchell DS, Chiappetta C \& Stancel GM 1988 Estrogen regulation of c-fos messenger ribonucleic acid. Molecular Endocrinology 2 946-951.

Lupulescu A 1993 Estrogen use and cancer risk: a review. Experimental Clinical Endocrinology 101 204-214.

McGuire WL 1978 Hormone receptors: their role in predicting prognosis and response to endocrine therapy. Seminars in Oncology 5 428-433.

McInerney EM, Weis KE, Sun J, Mosselman S \& Katzenellenbogen BS 1998 Transcription activation by the human estrogen receptor subtype beta (ER beta) studied with ER beta and ER alpha receptor chimeras. Endocrinology 139 45134522.

MacMahon B, Cole P, Lin TM, Lowe CR, Mirra AP, Ravnihar B, Salber EJ, Valaoras VG \& Yuasa S 1970 Age at first birth and breast cancer risk. Bulletin of the World Health Organization $\mathbf{4 3}$ 209-221.

May FEB \& Westley BR 1995 Estrogen regulated messenger RNAs in human breast cancer cells. Biomedicine and Pharmacotherapy 49 400-414.

Migliaccio A, Di Domenico M, Castoria G, De Falco A, Bontempo P, Nola E \& Auricchio F 1996 Tyrosine kinase/p21 ras /

MAP-kinase pathway activation by estradiol-receptor complex in MCF-7 cells. EMBO Journal 15 1292-1300.

Migliaccio A, Piccolo D, Castoria G, Di Domenico M, Bilancio A, Lombardi M, Gong W, Beato M \& Auricchio F 1998 Activation of the Src/p21ras/Erk pathway by progesterone receptor via cross-talk with estrogen receptor. EMBO Journal 17 2008-2018.

Molloy CA, May FE \& Westley BR 2000 Insulin receptor substrate-1 expression is regulated by estrogen in the MCF-7 
human breast cancer cell line. Journal of Biological Chemistry 275 12565-12571.

Montano MM, Muller V, Trobaugh A \& Katzenellenbogen BS 1995 The carboxy-terminal F domain of the human estrogen receptor: role in the transcriptional activity of the receptor and the effectiveness of antiestrogens as estrogen antagonists. Molecular Endocrinology 9 814-825.

Mosselman S, Polman J \& Dijkema R 1996 ER beta: identification and characterization of a novel human estrogen receptor. FEBS Letters 392 49-53.

Murphy LC \& Watson P 2002 Steroid receptors in human breast tumorigenesis and breast cancer progression. Biomedicine and Pharmacotherapy 56 65-77.

Musgrove EA \& Sutherland RL 1993 Acute effects of growth factors on T-47D breast cancer cell cycle progression. European Journal of Cancer 29A 2273-2279.

Oh Y, Gucev Z, Ng L, Muller HL \& Rosenfeld RG 1995 Antiproliferative actions of insulin-like growth factor binding protein (IGFBP)-3 in human breast cancer cells. Progress in Growth Factor Research 6 503-512.

Osborne CK, Coronado EB, Kitten LJ, Arteaga CI, Fuqua SA, Ramasharma K, Marshall M \& Li CH 1989 Insulin-like growth factor-II (IGF-II): a potential autocrine/paracrine growth factor for human breast cancer acting via the IGF-I receptor. Molecular Endocrinology 3 1701-1709.

Osborne CK, Clemmons DR \& Arteaga CL 1990 Regulation of breast cancer growth by insulin-like growth factors. Journal of Steroid Biochemistry and Molecular Biology 37 805-809.

Paik S 1992 Expression of IGF-I and IGF-II mRNA in breast tissue. Breast Cancer Research and Treatment 22 31-38.

Papa V, Gliozzo B, Clark GM, McGuire WL, Moore D, Fujita-Yamaguchi Y, Vigneri R, Goldfine ID \& Pezzino V 1993 Insulin-like growth factor-I receptors are overexpressed and predict a low risk in human breast cancer. Cancer Research $\mathbf{5 3}$ 3736-3740.

Perks CM \& Holly JM 2000 Insulin-like growth factor binding proteins (IGFBPs) in breast cancer. Journal of Mammary Gland Biology and Neoplasia 5 75-84.

Pertzelan A, Yalon L, Kauli R \& Laron Z 1982 A comparative study of the effect of oestrogen substitution therapy on breast development in girls with hypo- and hypergonadotrophic hypogonadism. Clinical Endocrinology 16 359-368.

Peyrat JP, Bonneterre J, Hecquet B, Vennin P, Louchez MM, Fournier C, Lefebvre J \& Demaille A 1993 Plasma insulin-like growth factor-1 (IGF-1) concentrations in human breast cancer. European Journal of Cancer 29A 492-497.

Pollak MN, Huynh HT \& Lefebvre SP 1992 Tamoxifen reduces serum insulin-like growth factor I (IGF-I). Breast Cancer Research and Treatment 22 91-100.

Portier CJ 2002 Endocrine dismodulation and cancer. Neuroendocrinology Letters 23 (Suppl 2) 43-47.

Ram PT, Kiefer T, Silverman M, Song Y, Brown GM \& Hill SM 1998 Estrogen receptor transactivation in MCF-7 breast cancer cells by melatonin and growth factors. Molecular and Cellular Endocrinology 141 53-64.

Rinderknecht E \& Humbel RE $1976 a$ Amino-terminal sequences of two polypeptides from human serum with nonsuppressible insulin-like and cell-growth-promoting activities: evidence for structural homology with insulin B chain. PNAS 73 4379-4381.

Rinderknecht E \& Humbel RE $1976 b$ Polypeptides with nonsuppressible insulin-like and cell-growth promoting activities in human serum: isolation, chemical characterization, and some biological properties of forms I and II. PNAS 73 2365-2369.

Rinderknecht E \& Humbel RE $1978 a$ Primary structure of human insulin-like growth factor II. FEBS Letters 89 283-286.

Rinderknecht E \& Humbel RE $1978 b$ The amino acid sequence of human insulin-like growth factor I and its structural homology with proinsulin. Journal of Biological Chemistry 2532769 2776.

Rocha RL, Hilsenbeck SG, Jackson JG, Lee AV, Figueroa JA \& Yee D 1996 Correlation of insulin-like growth factor-binding protein-3 messenger RNA with protein expression in primary breast cancer tissues: detection of higher levels in tumors with poor prognostic features. Journal of the National Cancer Institute 88 601-606.

Rocha RL, Hilsenbeck SG, Jackson JG, VanDenBerg CL, Weng C, Lee AV \& Yee D 1997 Insulin-like growth factor binding protein-3 and insulin receptor substrate-1 in breast cancer: correlation with clinical parameters and disease-free survival. Clinical Cancer Research 3 103-109.

Roger P, Sahla ME, Makela S, Gustafsson JA, Baldet P \& Rochefort H 2001 Decreased expression of estrogen receptor beta protein in proliferative preinvasive mammary tumors. Cancer Research 61 2537-2541.

Sachdev D \& Yee D 2001 The IGF system and breast cancer. Endocrine-Related Cancer 8 197-209.

Salmon WD \& Daughaday WH 1957 A hormonally controlled serum factor which stimulates sulfate incorporation by cartilage in vitro. Journal of Laboratory and Clinical Medicine 49 825.

Shafie SM 1980 Estrogen and the growth of breast cancer: new evidence suggests indirect action. Science 209 701-702.

Silberstein GB, Van Horn K, Shyamala G \& Daniel CW 1994 Essential role of endogenous estrogen in directly stimulating mammary growth demonstrated by implants containing pure antiestrogens. Endocrinology 134 84-90.

Steenbergh PH, Holthuizen PE \& Sussenbach JS 1997 Molecular aspects of the insulin-like growth factor (IGF) genes. Advances in Molecular and Cellular Endocrinology 1 83-121.

Stoica A, Saceda M, Fakhro A, Joyner M \& Martin MB 2000 Role of insulin-like growth factor-I in regulating estrogen receptor-alpha gene expression. Journal of Cellular Biochemistry 76 605-614.

Sun M, Paciga JE, Feldman RI, Yuan Z, Coppola D, Lu YY, Shelley SA, Nicosia SV \& Cheng JQ 2001 Phosphatidylinositol-3-OH kinase (PI3K)/AKT2, activated in breast cancer, regulates and is induced by estrogen receptor alpha (ERalpha) via interaction between ERalpha and PI3K. Cancer Research 61 5985-5991.

Surmacz E 2000 Function of the IGF-I receptor in breast cancer. Journal of Mammary Gland Biology and Neoplasia 5 95-105.

Surmacz E \& Burgaud JL 1995 Overexpression of insulin receptor substrate 1 (IRS-1) in the human breast cancer cell line MCF-7 induces loss of estrogen requirements for growth and transformation. Clinical Cancer Research 1 1429-1436.

Surmacz E, Guvakova MA, Nolan MK, Nicosia RF \& Sciacca L 1998 Type I insulin-like growth factor receptor function in breast cancer. Breast Cancer Research and Treatment 47 255267.

Tora L, White J, Brou C, Tasset D, Webster N, Scheer E \& Chambon P 1989 The human estrogen receptor has two independent nonacidic transcriptional activation functions. Cell 59 477-487. 
Toropainen E, Lipponen P \& Syrjanen K 1995a Expression of insulin-like growth factor I (IGF-I) in female breast cancer as related to established prognostic factors and long-term prognosis. European Journal of Cancer 31A 1443-1448.

Toropainen EM, Lipponen PK \& Syrjanen KJ 1995b Expression of insulin-like growth factor II in female breast cancer as related to established prognostic factors and long-term prognosis. Anticancer Research 15 2669-2674.

Trichopoulos D, MacMahon B \& Cole P 1972 Menopause and breast cancer risk. Journal of the National Cancer Institute $\mathbf{4 8}$ 605-613.

Tsai MJ \& O'Malley BW 1994 Molecular mechanisms of action of steroid/thyroid receptor superfamily members. Annual Review of Biochemistry 63 451-486.

Ullrich A, Gray A, Tam AW, Yang-Feng T, Tsubokawa M, Collins C, Henzel W, Le Bon T, Kathuria S \& Chen E 1986 Insulin-like growth factor I receptor primary structure: comparison with insulin receptor suggests structural determinants that define functional specificity. EMBO Journal 5 2503-2512.

Van der Burg B, Rutteman GR, Blankenstein MA, De Laat SW \& Van Zoelen EJJ 1988 Mitogenic stimulation of human breast cancer cells in a growth factor-defined medium: synergistic action of insulin and estrogen. Journal of Cellular Physiology 134 101-108.

Van der Burg B, Isbrucker L, Selm-Miltenburg AJ, De Laat SW \& Van Zoelen EJJ 1990 Role of estrogen-induced insulin-like growth factors in the proliferation of human breast cancer cells. Cancer Research 50 7770-7774.
Venkitaraman AR 2002 Cancer susceptibility and the functions of BRCA1 and BRCA2. Cell 108 171-182.

Wakefield LM, Piek E \& Bottinger EP 2001 TGF-beta signaling in mammary gland development and tumorigenesis. Journal of Mammary Gland Biology and Neoplasia 6 67-82.

Weisz A \& Bresciani F 1993 Estrogen regulation of proto-oncogenes coding for nuclear proteins. Critical Reviews in Oncogenesis 4 361-388.

Yee D, Cullen KJ, Paik S, Perdue JF, Hampton B, Schwartz A, Lippman ME \& Rosen N 1988 Insulin-like growth factor II mRNA expression in human breast cancer. Cancer Research 48 6691-6696.

Yee D, Paik S, Lebovic GS, Marcus RR, Favoni RE, Cullen KJ, Lippman ME \& Rosen N 1989 Analysis of insulin-like growth factor I gene expression in malignancy: evidence for a paracrine role in human breast cancer. Molecular Endocrinology 3 509517.

Yu H, Levesque MA, Khosravi MJ, Papanastasiou-Diamandi A, Clark GM \& Diamandis EP 1996 Associations between insulin-like growth factors and their binding proteins and other prognostic indicators in breast cancer. British Journal of Cancer 74 1242-1247.

Zwijsen RML, Wientjens E, Klompmaker R, Van der Sman J, Bernards R \& Michalides RJAM 1997 CDK-independent activation of estrogen receptor by cyclin D1. Cell $\mathbf{8 8} 405-415$.

Zwijsen RML, Buckle RS, Hijmans EM, Loomans CJM \& Bernards R 1998 Ligand-independent recruitment of steroid receptor coactivators to estrogen receptor by cyclin D1. Genes and Development 12 3488-3498. 